\title{
A contracorrente: o pensamento de Clastres na Filosofia Política
}

\section{The countercurrent: the Clastresian thought in Political Philosophy}

\author{
Tédney Moreira da Silva ${ }^{1}$
}

\begin{abstract}
Resumo
Este artigo estuda a obra de PIERRE CLASTRES (1934-1977), filósofo e antropólogo francês cujos estudos etnológicos centraram-se em Antropologia Política, com vistas à investigação do poder nas ditas sociedades primitivas, e operaram uma alteração na determinação do objeto de estudo dessa ciência. O trabalho destina-se à exposição da construção de sua antropologia política geral, voltada que está a desmitificar as sociedades indígenas como sociedades sem Estado, para encará-las como sociedades contra o Estado, opostas à organização estatal que caracteriza a comunidade política europeia e grande parte das sociedades influenciadas (ou determinadas) por sua cosmovisão. O artigo divide-se em duas etapas: a primeira está voltada às sociedades contra o Estado, acerca das quais dissertou o filósofo-antropólogo, buscando trilhar o caminho que o levará a expor a necessidade de uma revolução copernicana nos estudos da origem do poder. A segunda parte é o retorno dos estudos etnográficos e etnológicos à Filosofia Política, trata dos inomináveis que somos, aqueles que abdicaram da liberdade para aderir ao modelo de opressão, que superaram a animalidade indesejável, mas se desnaturaram em servos de outros homens, seus iguais.
\end{abstract}

Palavras-chave: Filosofia Política. Antropologia política. Poder. Sociedades indígenas. Chefia indígena. Etnocentrismo.

\begin{abstract}
This paper studies the work of PIERRE CLASTRES (1934-1977), a French philosopher and anthropologist whose ethnological studies focus on Political Anthropology seeking the investigation of power within the so-called primitive societies, by making a change in the determination of the study subject matter of this science. It intends to show the construction of his general political anthropology aimed to demystify Indigenous societies as societies without State, and to view them as societies against the State, opposed to the state organization which characterizes the European political community and most societies influenced (or determined) by their cosmovision. This paper is split into two stages: the first is dedicated to societies against the State, which the philosopher-anthropologist discussed about, seeking to trail the road that would lead him to expose the need of a Copernicus revolution in the studies on the origin of power. The second stage deals with the return of ethnographic and ethnologic studies to Political Philosophy, examining our characteristic of being unnamable, those who have forgone freedom in order to abide by a model of oppression, those who overcame undesired animality, but denatured themselves into vassals of other men, their equals.

Keywords: Political philosophy. Political anthropology. Power. Indigenous societies. Indigenous leadership. Ethnocentrism.
\end{abstract}

\footnotetext{
${ }^{1}$ Advogado. Graduado em Direito pela Faculdade de Direito da Universidade Presbiteriana Mackenzie e em Filosofia pela Faculdade de Ciências Humanas e Sociais da Universidade São Judas Tadeu.
} 


\section{Introdução}

Este artigo $^{1}$ destina-se ao estudo da etnologia empreendida por Clastres e propõe-se a dialogar com aspectos centrais da Filosofia Política, como a definição de poder político e seus agentes. Para tanto, valemo-nos da leitura de duas obras centrais de seu trabalho etnológico ("A sociedade contra o Estado" e "Arqueologia da Violência"), bem como de outras obras filosóficas com as quais travou contato e serão serão pormenorizadas ao longo do texto. Isso porque, o filósofo-antropólogo estava voltado à construção de uma antropologia política geral que abarcasse, em seu conteúdo, também as conclusões obtidas por meio da análise do poder nas ditas sociedades primitivas. No entanto, podem-se inferir as profundas alterações que essas conclusões produziram no acervo conceitual da Filosofia Política tradicional que, em geral, prescinde de características como coercibilidade e hierarquia, para delimitar o que se identifica socialmente como poder.

Aliás, por essa identificação (entre poder e coerção), opõem-se as sociedades civilizadas das chamadas primitivas ou arcaicas, de sorte que somente as relações sociais de comando e obediência, bem como as hierarquizadas, é que puderam ser valoradas como sendo verdadeiramente políticas.

Esta valoração, aliás, é consentânea ao movimento de determinação das sociedades primitivas $^{3}$ por caracteres de pura negatividade: são sociedades sem escrita, satisfeitas por uma economia de subsistência (como economia precária e quase insuficiente às demandas da coletividade) e, principalmente, são sociedades sem Estado - uma vez que por meio da organização estatal é que as relações verdadeiramente políticas (isto é, relações de comando e obediência) puderam ser identificadas na História.

É conhecido entre nós, por exemplo, o mote "sem fé, sem lei, sem rei", usado pelos viajantes dos séculos XVI e XVII, que se reporta às sociedades indígenas e à sua conceituação pela negação dos três pilares de formação dos Estados modernos.

O espaço ocupado pelo poder político nas sociedades primitivas é, pois, quase nulo ou, contrariamente, exacerbado. A ausência do poder de coerção e de relações hierárquicas nessas sociedades qualifica-as como sociedades na infância dos povos, do mesmo modo como sua presença sempre foi vista como exemplo de pura selvageria: a exata medida do exercício desse poder não lhes é tangível, colocando-as sempre às margens da posição central que ocupamos.

Por essa razão, a afirmação de Clastres (2003, p. 60) de que "[...] o poder é exatamente o que as sociedades quiseram que ele fosse." impõe-nos logo um desconcerto evidente: a questão do poder político não se subsume a uma fórmula universal. Assim, não são as sociedades as que se dividem em dois grandes grupos - de sociedades com e sem poder - mas, sim, a forma como os modos diversos de exercício do poder político é que se encontram-se representados num binômio, pois é um poder se que realiza com ou sem coerção.

Formado em Filosofia pela Sorbonne, Pierre Clastres (1934-1977) iniciou seus estudos etnológicos durante a licenciatura, freqüentando os cursos do antropólogo Claude Lévi-Strauss, ministrados no Collège de France a partir de

${ }^{2}$ Este artigo foi apresentado, sob forma monográfica - e, portanto, mais aprofundada, à Faculdade de Ciências Humanas e Sociais, da Universidade São Judas Tadeu (SP), como condição à obtenção do título de bacharelado em Filosofia, no ano de 2010.

${ }^{3}$ A utilização de expressões tais como sociedades primitivas, originárias e mesmo sociedades indígenas, desde já, coloca-nos a dificuldade lingüística intrínseca para se versar seriamente sobre tais comunidades, respeitando-se, pois, suas organizações política, econômica, cultural e social. Isto porque todas elas estão eivadas de certo evolucionismo que dispõe as sociedades em graus de desenvolvimento diversos, tendo-se o último patamar (mais elevado) representado pela civilização ocidental da qual fazemos parte. Ainda, esta qualificação generalizante suprime a diversidade existente, nivelando todas as sociedades por características que são tão-somente circunstancialmente semelhantes. Superada, entretanto, a discriminação que poderia provir destas expressões, utilizá-las-emos em consonância à escrita clastriana e ao discurso político tradicional que se deseja investigar. 
1960. Ele realizou sua primeira experiência de campo acompanhado de sua esposa, Helène Clastres, entre os Guayaki, no Paraguai, já em 1963. Sua tese foi defendida em 1965 ("La Vie sociale d'une tribu nomade: les Indiens Guayaki Du Paraguay"), lecionando, posteriormente, na cidade de São Paulo, no Departamento de Ciências Sociais da Universidade de São Paulo. Seus ensaios ulteriores, provenientes de pesquisas realizadas em comunidades indígenas da América do Sul, entre os anos de 1965 e 1968, são reunidos em suas obras conhecidas - dentre elas, "A Sociedade contra o Estado".

Outras pesquisas de campo foram efetuadas por Clastres na década de 1970. Pode-se mencionar sua passagem pela região amazônica venezuelana (de 1970 a 1971), com os Yanomami, bem como sua estadia com os Guarani, em São Paulo, no ano de 1974. As investigações desse período foram reunidas num volume intitulado Arqueologia da violência: pesquisas em antropologia social, publicado em 1980, sendo, pois, uma obra póstuma, dado seu falecimento, ocorrido em 1977, num acidente automobilístico.

Não fosse a inesperada interrupção causada por sua morte, Clastres teria realizado o percurso que o conduziria a um retorno à Filosofia (muito embora, frise-se, fosse de seu interesse primordial a constituição de uma antropologia politica geral). De fato, seus estudos etnológicos têm proveito não tão-somente à Antropologia - especialmente à Antropologia Social - mas têm repouso no âmbito da Filosofia Política, já que a revolução copernicana que propusera em A Sociedade contra o Estado - "revolução" que transformaria a concepção tradicional unilateral de poder político como sendo o mero exercício final da violência entre dominantes e dominados - surtiria efeitos para além das fronteiras daquela ciência social.

Basta relembrarmos a concepção hobbesiana de organização da sociedade, que tinha por fundamento e justificativa o medo recíproco entre os seus membros, que eram iguais. A natureza humana, repleta de imperfeições ocasionadas por paixões e egoísmos, urge por um controle externo, ainda que por todos pactuado. Assim,

[q]uando se faz um pacto em que ninguém cumpre imediatamente a sua parte, e uns confiam nos outros, na condição de simples natureza (que é uma condição de guerra de todos os homens contra todos os homens), a menor suspeita razoável torna nulo esse pacto. Mas se houver um poder comum situado acima dos contratantes, com direito e força suficiente para impor o seu cumprimento, ele não é nulo (HOBBES, 2008, p. 118).

Esta legitimação do uso da violência pelo Estado possibilitou a sua confusão com a natureza do poder político, negando-se às sociedades primitivas o status de sociedades políticas, quando não são policiadas. Em verdade, é justamente por reconhecer a essência do poder como violência que as sociedades indígenas contrapõem-se ao Estado, como escolha genuinamente política, isto é, as sociedades primitivas não desconhecem o poder coercitivo, mas optam por não exercê-lo.

Não são estas as únicas conclusões críticas à reflexão política a que chega Clastres. Mesmo à concepção marxista de poder político o pensamento clastriano o autor apresenta seus argumentos contrários. Afirma-se no Manifesto Comunista, por exemplo (que fora publicado em Londres, no final de fevereiro ou início de março de 1848, por Marx e Engels), que "[o] poder político é o poder organizado de uma classe para a opressão de outra" (ENGELS; MARX, 2007, p. 59). O Estado moderno, enfim, teria resultado duma luta de classes com a vitória da burguesia, como classe revolucionária que é. Assim, afirmam Marx e Engels, “[...] com o estabelecimento da grande indústria e do mercado mundial, conquistou, finalmente, a soberania política exclusiva no Estado representativo moderno. O executivo no Estado moderno não é senão um comitê para gerir os negócios comuns de toda a classe burguesa" (ENGELS; MARX, 2007, p. 42).

Clastres é contrário ao argumento de que as 
relações de hierarquia, mando e subordinação proviriam de relações econômicas desiguais. Afinal, não é a partir da luta de classes marxista que se deve tentar localizar os fundamentos e o espaço do poder político. Antes, o inverso: da instauração do poder político coercitivo averiguamos as relações de desigualdade serem instaladas, em todos os níveis da vida social, não só no econômico.

Por essas razões, trata-se efetivamente da revolução copernicana o que se pretende operar ante a tradição da Filosofia Política, já que se desloca o poder político daquele centro unicamente vinculado à coerção (CLASTRES, 2004, p. 146).

Dessa tarefa Clastres incumbiu a Antropologia Social que, ademais, deveria começar por se desprender da "velha convicção ocidental", concernente ao evolucionismo, "[...] de que a história tem um sentido único, de que as sociedades sem poder são a imagem daquilo que não somos mais e de que a nossa cultura é para elas a imagem do que é necessário ser" (CLASTRES, 2003, p. 34). Desfeitos esses pressupostos, poder-se-ia constituir uma antropologia política geral, que abarcasse a totalidade dos fenômenos políticos nas sociedades ditas civilizadas ou primitivas, perquirindo-se, desta feita, seriamente a respeito do poder político.

Porém, no decorrer de seus estudos etnológicos (e de suas reflexões propriamente filosóficas), Clastres desvenda um problema (outrora, em outros termos, já enaltecida por La Boétie) que, entretanto, restará sem solução: afinal, quais circunstâncias ou elementos permitiram a criação do Estado? Se é, enfim, um construto na história, como fenômeno limitado no espaço e no tempo, o que o criara, o que o mantém e mesmo o que o manterá? Se o poder político pode ser exercido sem coerção, o que fez com que determinadas sociedades optassem pela relação comando-obediência? Em resumo, questiona-se: o que é a sociedade? O que é a história?

O empreendimento de Pierre Clastres é deveras ambicioso, mas inevitável, caso se queira investigar com seriedade o lugar do poder político. Trata-se, pois, de uma tarefa que se circunscreve além dos limites da ciência antropológica e requer do filósofo político uma reflexão acerca dos fundamentos de sua argumentação e dos efeitos aí gerados. Justifica a afirmação anterior o fato de o etnocentrismo da cultura e civilização ocidentais, que marca o próprio ato de pensar, ser também, no mais das vezes, etnocida: na ânsia por delimitar as sociedades primitivas como lugares da opressão ou selvageria, veda-se-lhes o direito à diferença.

Trata-se, pois, de construir e fazer valer uma contracorrente (CLASTRES, 2004, p. 201) ao tradicionalismo filosófico, em consonância até aos escritos de Montaigne e de La Boétie no que diz respeito à intangível origem do Estado ou, em melhor exposição, à estranha separação do poder da sociedade que o deveria fundamentar.

Para compreendermos o movimento realizado pelo filósofo e antropólogo, desenvolveremos o texto em duas etapas. A primeira trata de seus estudos etnológicos, identificando o poder não-coercitivo nas sociedades primitivas, como contrapostas ao Estado. Depois, num segundo movimento, tentaremos ressaltar os pontos que conflitam com o bojo conceitual da Filosofia Política tradicional, ressaltando nos escritos clastrianos as críticas e reflexões que podem ser realizadas à civilização e cultura ocidentais.

\section{A Sociedade Contra o Estado}

A tradição filosófica-política é unânime em reconhecer no poder a capacidade de se fazer valer a vontade daquele que o detém sobre os demais, dentro duma relação de comando e obediência. Assim, no contato com povos indígenas na Era das Navegações, entre os séculos XV e XVII, as especulações acerca de sua origem, estado de sua humanidade, não podiam desvincular-se desta verdade: as sociedades indígenas, que em sua grande maioria não estavam estruturadas sob regimes de poder político coercitivo, não detinham, efetivamente, a qualidade de serem politicas, pois seus chefes eram chefes sem poder. 
Os escritos dos viajantes e cronistas dão conta desta realidade abstrusa: o que há de mais estranho a um indígena é dar e receber ordens. Dois são, portanto, os regimes atribuídos à organização das sociedades primitivas: um regime político despótico, tirânico, que foi próprio da antiga civilização incaica, e outro anárquico, estagnado, no qual grande parte das sociedades indígenas se enquadra, especialmente aquelas localizadas no interior da região amazônica, apenas como exemplo comum à América do Sul. Justapostas no excesso ou na falta, as sociedades indígenas estão, de qualquer modo, à beira da medida exata do poder político.

Dentro dessa “macro-tipologia dualista", relevante identificação do político ocorrerá nas sociedades policiadas (típicas da cultura ocidental européia), isto é, naquelas em que o poder somente se exerce por meio da violência, acatada pelos demais membros como algo institucionalizado, estando todos insertos numa classificação hierarquizada (CLASTRES, 2003, p. 30-31).

A apreensão das sociedades indígenas dentro dessas duas categorias espraia-se no pensamento antropológico, que passa a estudá-las sob critérios de arcaísmo, e firma também a perspectiva filosófica de que o poder só se pode exercer nas relações de coerção. Eis a orientação de Jean-William Lapierre, em seu Essai sur le fondement du pouvoir politique, a qual se opõe Pierre Clastres. Ao investigar o fundamento do poder político nas sociedades primitivas, aquele antropólogo utiliza-se de terminologias que deixam claros seus pressupostos científicos: são sociedades em estado embrionário do poder político, que pode desenvolver-se, elevarse (CLASTRES, 2003, p. 31). Esses argumentos de cunho biológico descrevem bem a visão das sociedades indígenas como aquém do "verdadeiro poder".

Essa compreensão é fruto do etnocentrismo, considerado uma propriedade formal de toda formação cultural (CLASTRES, 2004, p. 86). Para o filósofo e antropólogo, “[c]hama-se etnocentrismo essa vocação de avaliar as diferenças pelo padrão da própria cultura" e "[...] aparece então como a coisa do mundo mais bem distribuída e, desse ponto de vista pelo menos, a cultura do Ocidente não se distingue das outras" (CLASTRES, 2004, p. 85-86). Mas, se é justificável a permanência do etnocentrismo para padrões culturais, não o é do ponto de vista da pesquisa científica e da reflexão filosófica (CLASTRES, 2003, p. 36).

Os estudos etnológicos aproximam-nos das sociedades primitivas e desvendam aí os contornos de um poder que se exerce sem violência, se pudermos, como afirma Clastres, apontar dois modos de exercício do poder: coercitivo e não-coercitivo, dado que, de qualquer modo, o poder político é imanente ao social e, pois, universal (CLASTRES, 2003, p. 37). O poder político como coerção é um “caso particular" que não tem razão científica para ser privilegiado como "[...] o princípio de explicação de outras modalidades diferentes" (CLASTRES, 2003, p. 37), pois, “[p]odemos pensar o político sem a violência, mas não podemos pensar o social sem o político; em outros termos, não há sociedades sem poder" (CLASTRES, 2003, p. 38).

Neste primeiro tópico, portanto, deter-nos-emos na investigação etnológica de Clastres acerca do modo de exercício do poder político nas sociedades primitivas, localizadas eminentemente na América do Sul, fazendo breve resumo de suas conclusões. De posse delas, vamos dialogar a seguir com as bases da Filosofia Política, presentes no segundo tópico.

\section{Papel da chefia indígena}

Uma característica notável da chefia indígena, já descrita pelos cronistas e viajantes dos séculos XVI e XVII, é a completa ausência de autoridade. De fato, a função política não parece diferenciarse das demais que se levam a cabo no interior da vida social. Em alguns povos até, como os Ona e os Yahgan da Terra do Fogo, a instituição da chefia inexiste, assim como na língua dos Jivaro não há 
vocábulo que designe o chefe (CLASTRES, 2003, p. 47).

Para investigar este fenômeno, Clastres retomará o trinômio de caracteres da chefia indígena levantado pelo antropólogo australiano Robert Harry Lowie (1883-1957), num artigo seu publicado no ano de 1948 (Social Organization), o qual tem por base sua recorrência nas culturas dos diversos povos indígenas do continente americano. São, pois, três as qualidades intrínsecas do titular chief (conforme a terminologia utilizada por Lowie): a) capacidade de moderação de conflitos e a conseqüente divisão do poder em civil e militar; b) generosidade no provimento e na repartição de bens e, por fim, c) boa oratória, configurando-se seu discurso como uma garantia da não-violência.

Para além do trinômio essencial, a poliginia aparece como uma quarta característica recorrente nas chefias indígenas dos povos ameríndios, muito embora não seja ela de ordem interna, mas externa, de sorte que se torna muito mais um critério objetivo de identificação do chefe, como contraprestação da comunidade à generosidade e à oratória, que um princípio individual de seu ânimo e espírito. Vejamos, pois, cada traço que contorna e define os chefes.

Primeiramente, é preciso salientar que a direção do grupo dar-se-á distintamente em tempos de guerra e em tempos de paz, de modo que a bipartição do poder em civil e militar é uma constante. É comum que, no curso de uma empreitada militar, o líder ou chefe indígena disponha de um poder quase absoluto de comando sobre os guerreiros, dada a ameaça que o próprio grupo sofre nessas situações excepcionais. Entretanto, essa potência logo cessará terminada a expedição, uma vez, portanto, que o grupo "[...] esteja em relação somente consigo mesmo" (CLASTRES, 2003, p. 48), como soem demonstrar os exemplos históricos concernentes aos Tupinambás e aos Jivaro, na América do Sul.

O poder, tal como comumente se exerce, é fundamentado no consenso dos membros da coletividade, de modo que cabe ao seu líder, pois, a função de pacificar as disputas internas e manter a harmonia grupal, sem se valer da força, cuja ilegitimidade seria auferida, porém apenas de suas virtudes e de seu prestígio. Essa "fragilidade permanente" do seu poder exigirá, como dependente dela, a "boa vontade" do grupo.

A generosidade apontada por Lowie como um dos traços marcantes da chefia indígena acaba por se caracterizar como sua servidão à obrigação de dar e, consequentemente, um compromisso com um quase direito da comunidade "[...] de submetê-lo a uma pilhagem permanente” (CLASTRES, 2003, p. 48).

Claude Lévi-Strauss, por exemplo, descreveu de modo meridiano o lugar da generosidade no cumprimento das obrigações que competem ao chefe indígena dos Nambikwara, no Estado de Mato Grosso, pois:

\begin{abstract}
[a] recusa em dar ocupa então mais ou menos o mesmo lugar, nessa democracia primitiva, que o voto de confiança num parlamento moderno. Quando um chefe chega a dizer: 'Basta de dar! Basta de ser generoso! Que outro seja generoso em meu lugar!', tem de estar realmente seguro de seu poder, pois seu reinado está passando pela mais grave crise (LÉVI-STRAUSS, 2004, p. 293-294).
\end{abstract}

O dom da oratória é, por fim, outra qualidade intrínseca presente à chefia indígena, já que a palavra (estendendo-a ao diálogo, como conversação e recurso para a mediação) apresenta-se como meio não-opressivo de resolução de conflitos e, conseqüentemente, "[...] se a linguagem é o oposto da violência, a palavra deve ser interpretada, mais do que como privilégio do chefe, como o meio de que o grupo dispõe para manter o poder fora da violência coercitiva, como a garantia repetida a cada dia de que essa ameaça está afastada" (CLASTRES, 2003, p. 62). Desse modo, pode-se afirmar que, ao chefe, a fala não transparece como um direito advindo de seu poder, mas antes é um dever dele derivado, pois aquele que se destina a ser chefe deve ser hábil no domínio das palavras.

Curiosamente, "[a] palavra do chefe não é dita 
para ser escutada" (CLASTRES, 2003, p. 171) e esse paradoxo resolve-se ao afirmar-se que, por ser o discurso do chefe um discurso de poder, e estar aquele separado deste na sociedade primitiva, a sua obrigação de submeter-se à fala não se confunde com comandos de autoridade (CLASTRES, 2003, p. 172).

Se, por um lado a capacidade de moderação, a generosidade e a oratória transparecem como símbolos do prestígio de que gozará o chefe indígena, não serão, por outro e por igual modo, símbolos duma relação desigual em termos de sobreposição do indivíduo sobre os demais ou de aquisição material de bens que oponha o líder à comunidade.

Isso ocorre, num primeiro momento, porque a função política só pode manifestar-se efetivamente se imanente for ao grupo, não havendo espaço para tal hierarquização entre os membros dele. A própria idéia de acumulação de riquezas e de lucro é avessa à importância política atribuída às atividades econômicas nas sociedades primitivas. Por fim, a interpretação do poder sob a lei da troca é demasiado insuficiente, pois levaria a um paradoxo.

Ainda que se considere a generosidade um símbolo de distinção da chefia indígena, por exemplo, é preciso reconhecer que as exigências da coletividade para se ver satisfeita excedem, em muitas ocasiões, a capacidade de o líder suprilas. A poliginia, dessa sorte, ingressaria nesta relação como uma contraprestação do grupo pela generosidade e oratória do chefe no exercício de suas funções políticas. A mulher é, pois, um valor nestas comunidades, principalmente entre os Nambikwara referidos.

Poder-se-ia cogitar a possibilidade de colocação das mulheres à disposição do líder como mãosde-obra para suprimento do quanto exigido pelo grupo - aproximando-se, desta feita, do poder como comando-obediência. Mas certos objetos requeridos não podem ser produzidos senão pelo líder, seja pela legitimidade da autoridade que os constrói, da qual dependem para serem considerados valiosos, seja pela especificidade do fabrico - como arcos e flechas para guerreiros e caçadores.

É por isso que da mesma forma como a poliginia se dá em apenas um sentido (da coletividade para o chefe), a generosidade também, mas no sentido contrário (do chefe para a coletividade). A relação, contudo, é evidentemente desigual. Afinal, a sociedade abdica de seus valores essenciais (que são as mulheres) em "troca" de escassos bens produzidos pelo chefe. Como explicar essa circunstância se o poder nas sociedades primitivas não se define por relações de hierarquia e coerção que justificaria a desigualdade instaurada?

A resposta está na própria negatividade que se atribui ao poder, sempre controlado pela comunidade. Se o trinômio de Lowie (generosidade, moderação e boa oratória) constitui os pontos fulcrais de caracterização das chefias indígenas, não é menos correto afirmar-se sua total submissão à sociedade a que se destina, vislumbrando-se um poder que se exerce não em razão do indivíduo que o detém, mas do grupo que o possui.

Em resumo: a impotência da chefia indígena está na recusa de um poder exterior à sociedade, de tal sorte que a palavra, como exposto, não seja uma ordem, mas um discurso voltado à moderação ou, no mínimo, um discurso improfícuo, se autoritário for; que a autoridade seja constantemente posta à prova e que o poder não seja violência.

\section{O riso: desmistificação do medo inspirado pelos Xamãs}

Outro mecanismo de neutralização da violência inerente ao poder é o simples riso. Mas essa simplicidade não se reporta, por certo, à tarefa que desempenha, como símbolo de desmistificação do medo e do respeito que inspira outra figura de autoridade nas sociedades primitivas: o xamã, ao qual se atribuem poderes sobrenaturais, importantes 
nos mecanismos de cura e prevenção de doenças, mas também de antecipação da morte (CLASTRES, 2003, p. 159-160).

Dois são os exemplos de mitos jocosos, presentes na narrativa dos Chulupi, habitantes do sul do Chaco paraguaio, que foram recolhidos, em 1966, por Pierre Clastres, como fontes para análise etnológica da utilização do riso como negatividade e controle do poder e que aqui serão resumidos.

No primeiro mito (nomeado "O homem a quem não se podia dizer nada" - título dado pelos próprios indígenas Chulupi), narram-se as dificuldades e confusões de um velho xamã que, a pedido da neta, inicia a travessia ${ }^{4}$, em companhia de outros xamãs, à procura da alma de seu bisneto, que padecia de febre. Glutão, distraído e voluptuoso, a expedição é sempre interrompida pelo guia para que seus viajantes comam, cacem e copulem, esquecendose da missão medicinal. Empreendida, por fim, a cura, entrega-se o velho xamã à libertinagem, aproveitando-se da inocência das netas para com elas manter relações sexuais.

O segundo mito (As aventuras dojaguar) também narra uma Grande Viagem, mas, desta feita, o seu atravessador é um animal. O jaguar, considerada uma forte fera habilidosa, é a personagem principal, e seu trajeto é um simples passeio, mas é interrompido, no entanto, por diversas armadilhas preparadas por aqueles que considera com verdadeiro desprezo. "Em resumo, esses dois mitos apresentam xamãs e jaguares como vítimas de sua própria estupidez e de sua própria vaidade, vítimas que por isso merecem, não a compaixão, mas o riso" (CLASTRES, 2003, p. 159).

Algumas observações devem ser feitas para compreensão da função catártica e de oposição ao poder desempenhada pelo ridículo das narrativas, e pelo riso em última instância. A primeira delas é que, entre os Chulupi e diversas outras tribos do Chaco paraguaio, os melhores feiticeiros são aqueles que podem se transformar em jaguares. Além disso, em outro mito chulupi, os jaguares eram efetivos xamãs, embora fossem maus, por fumarem seus próprios excrementos, no lugar do tabaco, e por devorarem seus pacientes, ao invés de curá-los. De qualquer modo, há identidade entre as personagens, ridiculamente caricaturadas nos mitos precedentes.

Nesse sentido, o riso é modo simbólico que opera a desmistificação do medo e respeito que inspiram o xamã e o jaguar. O poder que deles emana e pode constituir efetivo risco ao bem-estar de toda a coletividade é, miticamente, idiotizado e menosprezado pelos ouvintes, que, pela negação desse poder exterior, reafirmam sua superioridade.

Para Clastres, se "[...] longe de serem personagens cômicas, ambos [o xamã e o jaguar] são ao contrário seres perigosos, capazes de inspirar o medo, o respeito, o ódio, mas nunca a vontade de rir" (CLASTRES, 2003, p. 159), nos mitos eles são imbecilizados, pois naqueles reconhece-se "[...] uma intenção de mofa: os Chulupi fazem na esfera do mito aquilo que lhes é proibido no plano do real" (CLASTRES, 2003, p. 161).

\section{A inscrição da lei sobre os corpos: análise da $t$ ortura nas sociedades indigenas}

Outra característica marcante nas sociedades indígenas quanto à delimitação do poder político está presente na utilização de tortura como uma etapa de integração social. Conquanto nas sociedades estatais a lei escrita seja regrada em códigos e regulamentos separados dos indivíduos e de toda a coletividade, que a conhece num ato de subserviência, nas sociedades primitivas a lei faz inscrever-se nos seus corpos, o que se dá propriamente nos rituais de iniciação que marcam a passagem da adolescência à vida adulta.

\footnotetext{
4 Esta travessia corresponde à cura xamânica, em que se busca reintegrar ao corpo a alma, considerada uma prisioneira alhures. Esta expedição exige grande concentração do xamã, inspirado em sua tarefa medicinal.
} 
Nesses rituais iniciáticos, a tortura configura-se como essencial, pois a violência que se imprime ao iniciado, bem como a dor extrema suportada com silêncio e resignação, marcam em sua pele essa fase transitória e igualam-no aos demais conterrâneos, também um dia submetidos ao ritual. Além disso, uma vez fincada no corpo, a lei da sociedade não será jamais esquecida (CLASTRES, 2003, p. 201).

O sofrimento característico desses rituais tem funções específicas. Ele tanto avalia a resistência pessoal, quanto significa o pertencimento social do iniciado e sua inseparabilidade da lei ditada pela sociedade. O silêncio durante a tortura empregada, ademais, é visto como um consentimento daquele que ao ritual se submete, pelo que se demonstra "[...] o desejo de fidelidade à lei, a vontade de ser, sem tirar nem pôr, igual aos outros iniciados" (CLASTRES, 2003, p. 204).

Por essa razão, não se admite que a lei esteja separada daqueles que a elaboram e vivenciam, tornando-a inesquecível àqueles que a concebem e inviolável a todos, pois que a mesma violência fora e será sentida inexoravelmente por seus conterrâneos.

Esses dados serão relevantes ao cotejarmos, no segundo tópico, sua finalidade com aquelas buscadas pelas sociedades modernas civilizadas - em que há uma cisão entre sociedade e Estado, de sorte que a lei (em sentido amplo) torna-se o liame entre ambas as instâncias. Para finalizarmos esta primeira etapa de levantamento das conclusões etnológicas de Clastres, faz-se necessário observar sua interpretação da oponibilidade, em mitos indígenas, ao Uno - identificável como a causa de males. Vejamos.

\section{O uno e o múltiplo: escolha pelo poder não-c oercitivo}

Tupã, entidade mais elevada da teogonia indígena, cansado de sentir-se solitário, quis que a Terra, imperfeita como é, fosse habitada por pequenos seres, seus companheiros, que deveriam distraí-lo e com ele brincar. Assim nasceram os Últimos homens, ou seja, os Guarani.

Quem são os guaranis? Da grande nação cujas tribos, na aurora do século XVI, contavam seus membros às centenas de milhares, só subsistem ruínas hoje em dia: talvez cinco ou seis mil índios, dispersos em minúsculas comunidades que tentam sobreviver à margem do homem branco. Estranha existência a deles. Agricultores de queimada, mandioca ou o milho asseguram-lhes, bem ou mal, sua subsistência. E, quando precisam de dinheiro, alugam seus braços aos ricos exploradores da região. Uma vez decorrido o tempo necessário à aquisição da soma desejada, voltam silenciosamente às estreitas trilhas que se perdem no fundo da floresta. Pois a verdadeira vida dos índios guaranis desenrolase não às margens do mundo branco, mas muito mais longe, onde continuam a reinar os antigos deuses, onde nenhum olhar profanador do estrangeiro de boca grande corre o risco de alterar a majestade dos ritos.

Poucos povos testemunham uma religiosidade tão intensamente, vínculos tão profundos aos cultos tradicionais, vontade tão férrea de manter em segredo a parte sagrada de seu ser. Às investidas ora malsucedidas, ora brutais dos missionários opõem sempre uma recusa: “Guardem seu Deus! Temos os nossos!". E tão potente era seu zelo em proteger de toda conspurcação seu universo religioso, fonte e fim de sua força de viver, que até em data recente o mundo branco permanecia na total ignorância desse mundo dito selvagem, desse pensamento do qual não se sabe o que o torna mais admirável, se sua profundidade propriamente metafísica ou a suntuosa beleza da linguagem que o exprime. (CLASTRES apud JECUPÉ, 2002, p. 5)

Na genealogia da Terra imperfeita (Ywy mba'e megua), narrada pelos guarani, a desgraça é a ela inerente, as coisas são más e põem à prova constantemente os seus habitantes, já acostumados a esperar pelo dia que viverão na Terra sem males. Concede-se no mito a explicação para a maldade do mundo: as coisas são más porque, em sua totalidade, são Una.

Eis aí um diverso modo de encarar o perecível e indesejável, pois, para a antiga filosofia grega ocidental, é justamente a unidade o que constitui o Bem, o que se identifica à perfeição do cosmos e saber. Contudo, não é o Múltiplo o que se afirma diretamente na narrativa guarani, pois ao dizer que "as coisas em sua totalidade são uma" não se está a afirmar que o Um é o Todo. Essa categoria não se depreende por imediato do pensamento indígena. 
Antes, a coisa una - como corruptível, transitória e efêmera - é o signo do Finito, pois tudo o que se singulariza, individualiza-se de tal modo que encontra limites e a própria morte, sendo, assim, um ser incompleto e inacabado.

Na Ywy mba'e megua, isto é, no reino da morte (Terra imperfeita) vigora o princípio de identidade, já que, se se diz que um homem é um homem, afirma-se, também, que um homem não é um deus (CLASTRES, 2003, p. 190). O ato de nomear é o ato de assinalar sua singularidade, limitação e finitude. O não-Um é o reino da felicidade, é a Terra sem Mal (Ywy Mara-ey), uma vez que se refere aos seres completos.

Analogamente, as sociedades organizam-se sob signo da unidade e da multiplicidade, conforme se reconheça o Bem neste ou naquele locus.

O que se pode observar, por exemplo, como uma característica constante nas sociedades primitivas (embora não seja, por certo, a única explicação à diversidade de formas do exercício do poder político) é sua fragmentariedade, sua cisão em tribos menores com demografia e território pequenos. Nos chamados povos da Floresta, a organização social é complexa, definida por alianças políticas e pela exogamia, como forma de introduzir em cada demo uma multiplicidade de famílias que, unidas, podem efetivar o intercâmbio de mulheres para o estabelecimento de parceiros sexuais diversos e defender-se dos inimigos. Por meio desses casamentos, são garantidos direitos e deveres recíprocos entre as comunidades, instituindose um sistema político distinto dos demais "[...] por uma solidariedade revelada ocasionalmente em circunstâncias graves, pela certeza de cada coletividade de se saber rodeada, por exemplo, em caso de escassez ou de ataque armado, não de estrangeiros hostis, mas de aliados e parentes" (CLASTRES, 2003, p. 81).

Por outro lado, as sociedades com Estado, alicerçadas no pensamento grego ocidental e na religiosidade judaico-cristã, eminentemente, organizam-se sob a proeminência do uno, da busca pela centralização e unificação de propósitos. Busca-se alcançar o bem comum (desde a concepção liberal de Estado, com a Revolução Francesa, no século XVIII) identifica-se o poder numa entidade separada da sociedade, embora por ela legitimada, com a definição de relações de comando-obediência e hierarquia. Assim, conclui o filósofo e antropólogo, "[a]s sociedades primitivas são sociedades do múltiplo; as não primitivas, com Estado, são sociedades do uno. O Estado é o triunfo do uno" (CLASTRES, 2003, p. 241).

Duas, portanto, são as formas de exercício e de legitimação do poder político.

Nas sociedades com Estado, o poder, com sua natureza de evidente violência, ordena a comunidade, de tal sorte haver os que comandam e os que obedecem. Esses recepcionam as ordens, submetem-na à aplicação imediata, se reconhecerem sua obrigatoriedade (ou nela crerem), enquanto se concede aos comandantes o dever e direito de a todos imporem regramentos.

Por sua vez, nas sociedades sem Estado, o poder não se separa do corpo social. Antes, toda a sua organização está voltada para impedi-lo, para negativá-lo.

Espera-se do chefe indígena que seja bom mediador, bom orador e bom provedor de bens à comunidade. Mas tanto se contesta sua autoridade na resolução de conflitos, como não se ouve seu discurso e se exacerba no direito de exigir bens materiais. $\mathrm{O}$ chefe, assim, é um chefe sem poder. O papel que desempenha tem prestígio, mas ele não se dá pela submissão dos demais aos seus ditames egoísticos.

Ao mesmo tempo, ri-se daqueles que, por seus papéis, concentram uma grande autoridade em suas mãos. Os xamãs são ridicularizados, assim como o são os jaguares, como representantes míticos daqueles. O riso é signo do menosprezo ao poder excedente do social. 
Por fim, nos rituais iniciáticos, a juventude indígena é submetida à grande tortura: marca-se na sua pele, indelevelmente, a lei comum e a igualdade do iniciado aos demais membros. Testa-se sua resistência e obstinação em participar do todo social e, dessa forma, aquele que supera as dificuldades do rito não esquecerá sua fidelidade, não desejará a individualização extremada, a singularizarão do seu desejo de poder, pois sabe dos malefícios ocasionados pela segregação e pela desigualdade.

Se o Estado se tornou possível, em circunstâncias históricas precisas, identificá-las pode também elucidar as causas que o engendram e que podem encerrá-lo, muito embora, para essa tarefa, devase antes questionar o porquê de sua existência. Afinal, o que se observa nas sociedades primitivas é uma verdadeira escolha pelo não-poder, pela nãocoerção.

A essência severa do poder não é desconhecida das sociedades primitivas, como prova a etnologia empreendida ante as mais diversas comunidades indígenas, e ele é até mesmo identificado com as forças naturais. Sua cultura, como oposição ao poder, é também uma cultura de oposição à natureza, como "[...] negação de ambos, não no sentido em que poder e natureza seriam dois perigos diferentes, cuja identidade só seria aquela - negativa - de uma relação idêntica ao terceiro termo, mas no sentido em que a cultura apreende o poder como a ressurgência mesma da natureza" (CLASTRES, 2003, p. 61).

Opta-se, portanto, pela negatividade como mecanismo de controle do poder, mortífero risco à coexistência pacífica. Antes de ser uma sociedade sem Estado, a sociedade primitiva é uma sociedade contra o Estado, contra a sociedade do trabalho alienado e de produção de excesso inútil, contra a sociedade hierarquizada, classista e subserviente, contra a Sociedade do Uno. "Não resta dúvida que somente a interrogação atenta do funcionamento das sociedades primitivas permitirá esclarecer o problema das origens. E talvez a luz assim lançada sobre o momento do nascimento do Estado esclarecerá igualmente as condições de possibilidade (realizáveis ou não) de sua morte" (CLASTRES, 2004, p. 151).

De posse de breve esboço dos ensinamentos da antropologia política geral clastriana, tentaremos dialogar com os construtos da Filosofia Política contra os quais se choca, objetivando desvendar os fundamentos de nossa organização social e os mecanismos de manutenção do próprio Estado. Passemos á exposição.

\section{A Sociedade do Uno}

\section{Os inomináveis (o "Discurso da Servidão Voluntária”, de la boétie)}

A questão da origem do Estado, embora revivificada por Clastres, havia sido posta por Étienne de La Boétie (1530-1563), ao escrever o opúsculo intitulado "O nome do Um" ou "Discurso da servidão voluntária". Nele se questiona pela primeira vez como é possível que uma multidão submeta-se ao mando do Um, de um tirano ou de um superior hierárquico.

Aliás, o Um parece estabelecer uma ordem no caos, fazendo desaparecer as antinomias na sociedade. Mas a tirania, por diversas vezes, se beneficia da ambição e avareza daqueles que a propagam na sociedade, ou seja, daqueles que interiorizaram o esquema de dominação e se vêem como portadores do nome do Um, para exercerem um poder que lhes é desfavorável e cerceador da liberdade. O poder do Um, portanto, provém dos próprios subordinados.

Esta servidão voluntária faz dos homens (servis) os autores de sua própria desgraça, despojando o tirano de sua liberdade na exata medida em que se lhe deixa fazê-lo. De sua humanidade, rebaixam-se à condição de bestas, saciados na miserável garantia de segurança. Ou melhor: nem sequer aos animais podem esses servos se equipararem, pois “[...] desde 
los más grandes hasta los más pequeños, cuando son capturados, oponen tal resistência con garras, cuernos, pico y patas, que declaran suficientemente con ello cuánto estiman lo que pierden" (BOÉTIE, 2008, p. 33). Nascemos livres e com a paixão de conservar tal natureza, mas nos desnaturamos, servindo a um só como um "desgraçado vício" (BOÉTIE, 2008, p. 27).

Diferentemente de La Boétie, Clastres não considera esta desnaturalização humana um rebaixamento à animalidade, os demais animais só se submetem pelo medo que inspira o dominador. Sequer, por óbvio, uma elevação ao status de divindade: essa nova natureza (nem feroz, nem idílica) está presente nos homens servis aos mandos e desmandos de um tirano ou de um pequeno grupo de indivíduos e torna aqueles a tal condição habituados verdadeiros seres "inominados" (CLASTRES, 2004, p. 161).

A pergunta que se coloca, pois, é quanto às condições que possibilitam a desnaturação, sendo três as elucubrações de La Boétie para explicação da existência de tiranos: a) tirania que se dá pela força das armas (o que se pode contestar, uma vez que muitos são os servos e muitas, portanto, as possibilidades de se contrapor à vontade tirânica); b) tirania que se efetiva pelo costume de servir (sendo, também questionável, a sua manutenção sem se refletir sobre o querer do povo subordinado) e, por fim, c) aquela tirania que se exercita pela sedução dos tiranizados, organizados numa clara cadeia de tiranetes, de ambiciosos e avarentos que se beneficiam com a opressão e com a hierarquia.

Contra essa ordenação do social, La Boétie propunha o fortalecimento da amizade, isto é, do vínculo de fraternidade entre os membros de uma sociedade para afastá-la do poder tiranizado.

Nuestra naturaleza es tal que los comunes deberes de la amistad se llevan una buena parte del curso de nuestra vida: es razonable amar la virtud, estimar las buenas acciones, reconecer el bien de quien se ha recibido, y a menudo disminuir nuestra comodidad para aumentar el honor y las ventajas de aquel que amamos y lo merece (BOÉTIE, 2008, p. 26).
Todavia, embora a amizade apareça como valor central em La Boétie, a servidão voluntária é vista como uma doença incurável. O problema, então, resta apenas colocado, mas não solucionado.

O que possibilitou a criação do Estado e o que o mantém existente são os mesmos questionamentos aos quais chegara Pierre Clastres, que ao adentrando a antropologia investiga as sociedades indígenas para averiguar como é possível contrapô-lo historicamente.

Por essa razão, "La Boétie é, na realidade, o fundador desconhecido da antropologia do homem moderno, do homem das sociedades divididas. Ele antecipa, com mais de três séculos de distância, o empreendimento de um Nietzsche - mais ainda que o de um Marx - de pensar a degradação e a alienação" (CLASTRES, 2004, p. 161). Devese, contudo, superá-lo e buscar no pensamento etnológico as prováveis respostas para a existência de uma Sociedade do Uno.

A constituição de uma antropologia política geral foi a solução buscada por Clastres. A etnologia permitiria desvendar outros contornos do poder político, não abraçados pela Filosofia Política tradicional-como os demonstrados até aqui. Isso não significa, entretanto, que a etnologia empreendida fosse tão-só uma via à Filosofia. Em Clastres não há essa subordinação entre os saberes, mas um diálogo intenso pode ser observado. A Filosofia Política é posta em xeque pelos estudos etnológicos, empreendidos como uma contracorrente àquela: a interrelação entre Filosofia Política e Antropologia Política possibilitaria uma revisão simultânea de conceitos em ambas as áreas, pela conciliação de diferentes métodos de observação.

Se para La Boétie a subserviência de uma maioria aos comandos do "Um" era insuperável, em Clastres é possível antever quão frutíferos seriam os resultados advindos de sua antropologia política geral, como o desvelar eventual das condições históricas que marcaram a ruptura entre sociedade e Estado na comunidade ocidental européia (cujo modelo foi 
disseminado para além de fronteiras meramente territoriais) e o próprio fim desta cisão, uma vez esclarecidas aquelas condições. Eis o aspecto de positividade na filosofia-etnologia clastriana, marcado, no entanto, por uma contraposição (contracorrente) aos conceitos estanques em ambas as áreas nas quais se detém.

\section{A alienação política como antecedente da alienação econômica}

Para Pierre Clastres, diferentemente da concepção marxista, não é a alienação econômica a que engendra o poder coercitivo, mas exatamente o oposto: o trabalho alienado e a desigualdade econômica são decorrências de um poder político coercitivo e hierarquizado. José Arthur Giannotti, entretanto, contrapõe-se a essa visão , valendo-se dum método denominado dialética da sociabilidade.

Em "Trabalho e reflexão: ensaios para uma dialética da sociabilidade" (de inspiração fenomenológica), Giannotti constrói uma "ontologia do social", concebendo as idéias de Wittgenstein, Hegel e Marx como compreensão da dialética dos fenômenos sociais. O citado autor considera essa ontologia como um modelo lingüístico do real que possibilita identificar individualidades nela) ou, ainda, permite refletir acerca do lugar do fetichismo na determinação destes fenômenos (GIANNOTTI, 1983, p. 9).

Por essa razão, sua obra é destinada a investigar o trajeto dos fenômenos sociais às suas condições de aparecimento, valendo-se, então, das Ciências Sociais (em especial da Antropologia), bem como de outros ramos do saber, como a Lingüística, a Economia ou a História, para elaboração de sua crítica.

Embora tenha em Clastres a base para situar seu ponto de vista (GIANNOTTI, 1983, p. 13), aproxima-se de Marx, ainda que não pretenda fazer mera releitura de $O$ Capital.
Já em Clastres, contudo, busca-se superar a influência do marxismo na etnologia, que transpõe singelamente às sociedades indígenas um modelo de produção econômica que não lhes é pertinente por não ser desejado. Da mesma forma como as sociedades primitivas são contra o Estado, são, também, contra a produção econômica excedente, contra o trabalho alienado. "Antes de ser econômica, a alienação é política, o poder antecede o trabalho, o econômico é uma derivação do político, a emergência do Estado determina o aparecimento das classes" (CLASTRES, 2003, p. 216).

A troca e a reciprocidade são consideradas, pelo pensamento clastriano, como verdadeiros sustentáculos que fincam a economia primitiva numa economia em que os homens são senhores de suas atividades, sendo todos iguais e mediados pela lei de troca (já anteriormente referida como a troca de mulheres pelas palavras e bens provindos dos chefes indígenas). "Tudo se desarruma, por conseguinte, quando a atividade de produção se afasta do seu objetivo inicial, quando, em vez de produzir apenas para si mesmo, o homem primitivo produz também para os outros, sem troca e sem reciprocidade" (CLASTRES, 2003, p. 215).

$\mathrm{O}$ que fazem os etnólogos marxistas? Aplicam acriticamente às sociedades primitivas os pressupostos filosóficos (e, principalmente, históricos) do filósofo alemão. A narrativa mítica e os rituais religiosos são considerados o ópio dos indígenas; as relações de parentesco e a exogamia são encaradas como a formação de classes, enxergandose aí, sua infraestrutura; a introdução na comunidade de produtos industrializados é vista como a desigualdade na posse dos meios de produção. Dirá Clastres: que [...] O marxismo é um economismo, ele reduz o corpo social à infraestrutura econômica, o social é o econômico. E por isso os antropólogos marxistas são obrigados a extrair do corpo social primitivo o que, segundo eles, funciona noutras partes: as categorias de produção, de relações de produção, de desenvolvimento das forças produtivas, de exploração etc (CLASTRES, 2004, p. 225). 
Talvez por essa razão, para Giannotti (que se aproxima do marxismo), o que faz Clastres é uma simples metafísica (como a "metafisica de comer chocolates" pessoana), cujos esforços etnográficos e etnológicos não fornecem mais que uma tautologia. Reafirmam-se sem, no entanto, transcender seu próprio método e expor um modelo que justifique o lugar do poder não-coercitivo nas comunidades indígenas - o que justificaria a ausência, nelas, de um trabalho alienado e de produção excedente. Em última instância, o que Clastres realiza é um concerto de argumentos que explicam a lei de troca, mas não são hábeis a colocá-la como causa de relações econômicas pautadas na igualdade dos seus atores (GIANNOTTI, 1983, p. 159-160).

Esta metafísica clastriana, no entanto, assume uma positividade, conforme Bento Prado Jr, que prefaciou a "Arqueologia da violência: pesquisas de antropologia política". Isso porque em Clastres não há uma "ontologia da produção" a priori. Significa dizer que não são as relações econômicas desiguais as que instauram o poder coercitivo nas sociedades, mas o seu oposto.

Isso, por certo, não invalida, como quer Giannotti, as suas conclusões etnológicas. Antes, fazem emergir da experiência etnográfica dados que podem contribuir para a reflexão crítica do pensamento tradicional em filosofia política ${ }^{5}$. A produtividade econômica como economia de subsistência não é a economia da precariedade, mas do suficiente. A desigualdade decorrente da produção de bens em excesso é também indesejada. Isso fica claro quando se introduz nas comunidades indígenas artefatos da tecnologia do Ocidente.

Consideremos o potencial de um machado, por exemplo: "[...] ao descobrirem a superioridade produtiva dos machados dos homens brancos, os índios os desejaram, não para produzirem mais no mesmo tempo, mas para produzirem a mesma coisa num tempo dez vezes mais curto" (CLASTRES, 2003,p. 213-214). Os efeitos, contudo, são deletérios, "[...] pois, com os machados metálicos, irromperam no mundo primitivo dos índios a violência, a força, o poder, impostos aos selvagens pelos civilizados recém-chegados" (CLASTRES, 2003, p. 214).

Nas sociedades com Estado, o trabalho surge como um dos seus axiomas. "Produzir ou morrer, é a divisa do Ocidente" (CLASTRES, 2004, p. 92). O grau de civilização é consoante à capacidade de produção econômica de uma coletividade, considerandose precária toda organização que se paute numa produtividade voltada a saciar as necessidades e tão-só a satisfazê-las. O capitalismo, nesse sentido, caracteriza o Ocidente e compreende-se como um fim em si mesmo, sendo simultaneamente máquina de produção e de destruição. "Raças, sociedades, indivíduos; espaço, natureza, mares, florestas, subsolo: tudo é útil, tudo deve ser utilizado, tudo deve ser produtivo; de uma produtividade levada a seu regime máximo de intensidade" (CLASTRES, 2004, p. 91).

Aliás, é justamente seu regime de produção econômica o que torna a civilização ocidental inexoravelmente mais etnocida que qualquer outra sociedade (CLASTRES, 2004, p. 91). Vejamos.

\section{O etnocídio como essência do estado}

Como se afirmou anteriormente, o etnocentrismo, como capacidade própria da cultura de avaliar as diferenças a partir de si mesma, "[...] aparece como a coisa do mundo mais bem distribuída e, desse ponto de vista pelo menos, a cultura do Ocidente não se distingue das outras" (CLASTRES, 2004, p. 85-86). Todavia, é peculiar ao Ocidente a sua vocação para um etnocentrismo que acaba por ser, também, etnocida.

Partindo do conceito de genocídio, criado em 1946 no Tribunal de Nuremberg, para julgamento de um crime até então não tipificado, qual seja, o

${ }^{5}$ Clastres (2004, p.9). 
extermínio de pessoas baseado no racismo - como o fora o extermínio de judeus na Segunda Grande Guerra - o etnocídio foi formulado por etnólogos, dentre eles Robert Jaulin (1928-1996), para referir-se ao morticínio de populações indígenas do continente.

Ademais, conquanto o genocídio opera um extermínio do corpo, o etnocídio volta-se ao extermínio do espírito, significando que este crime "[...]é a destruição sistemática dos modos de vida e pensamento de povos diferentes daqueles que empreendem essa destruição"(CLASTRES,2004,p. 83).

O etnocídio, deste modo, parte do pressuposto de que o mal está contido na diferença e que esta pode ser alterada, melhorada, transformada. Para Pierre Clastres, ainda, "[a] negação etnocida do Outro conduz a uma identificação a si. Poder-se ia opor o genocídio e o etnocídio como duas formas perversas do pessimismo e do otimismo" (CLASTRES, 2004, p. 83), uma vez que o genocida considera intransponíveis os vícios que entende presentes na diversidade cultural e o etnocida crê poder melhorálos, destruindo-a.

O Ocidente demonstra-se, no contato com as sociedades primitivas, essencialmente etnocida. Basta recordarmos a missão evangelizadora empreendida no Novo Mundo (e que ainda se exerce, por certo) para averiguar que "[a] espiritualidade do etnocídio é a ética do humanismo" (CLASTRES, 2004, p. 84). E para compreender o porquê de ser o Ocidente etnocida é necessário debruçar-se sobre a própria história.

Um dos critérios basilares para identificação de uma sociedade civilizada e daquelas consideradas selvagens e bárbaras é o aparecimento ou não, entre elas, do Estado.

São civilizadas as sociedades com Estado, isto é, as sociedades cujos participantes abdicaram de sua liberdade em nome da centralização na figura duma entidade suprema do poder político, necessariamente coercitivo e, portanto, hierarquizado. Reduz-se ao
Uno a multiplicidade, em nome de um progresso e de uma única finalidade (atualmente, o bem comum). Por sua vez, são primitivas as sociedades sem Estado, ou seja, as sociedades que impedem, por um controle negativo, o poder coercitivo e as relações desiguais, contrapondo-se ao comando e à subserviência.

Esta " $[\ldots]$ força centrípeta que tende, quando as circunstâncias o exigem, a esmagar as forças centrífugas inversas" (CLASTRES, 2004, p. 87) é a de que se vale o Estado, recusando o múltiplo e a diversidade. Mas, embora o etnocídio constitua o Estado, como não se pode generalizar, sob pena de se incorrer no erro de raciocínio do próprio etnocídio, é necessário investigar o que faz com que determinados Estados sejam etnocidas e outros não.

Como exposto outrora, é o regime de produção econômica dos Estados, sempre a exigir o Todo, o que faz com que sejam mais etnocidas do que qualquer outra forma de organização social.

\section{O que diferencia o Ocidente é o capitalismo, enquanto impossibilidade de permanecer no aquém de uma fronteira, enquanto passagem para além de toda fronteira; é o capitalismo como sistema de produção para o qual nada é impossível, exceto não ser para si mesmo seu próprio fim [...] (CLASTRES, 2004, p. 91).}

Em outras palavras, foi o surgimento do Estado o que "[...] realizou a grande divisão tipológica entre selvagens e civilizados, e traçou uma indelével linha de separação além da qual tudo mudou, pois o Tempo se torna História" (CLASTRES, 2003, p. 217).

Afirmações dessa ordem suscitam outros questionamentos, mais inapreensíveis que os anteriores. Um deles é justamente o que é a História - já que se a considera início ou marco da sociedade dividida. Seria correto dizer que a História tem um começo? E as sociedades indígenas: seriam sociedades sem História? Se assim concluirmos, compreenderemos que 
[...] o que os selvagens nos mostram é o esforço permanente para impedir os chefes de serem chefes, é a recusa da unificação, é o trabalho de conjuração do Um, do Estado. A história dos povos que têm uma história é, diz-se, a história da luta de classes. A história dos povos sem história é, dir-se-á com ao menos tanta verdade, a história da sua luta contra o Estado (CLASTRES, 2003, p. 234).

Para essas questões não foram dadas respostas até então. $\mathrm{O}$ empreendimento clastriano representa uma contracorrente ao pensamento tradicional, pois as investigações inquietantes que se impõem ultrapassam a ciência social da qual parte para atingir outras dimensões do saber. É aqui que a Antropologia demonstra-se eficaz ferramenta, assim como a Filosofia, para pensar não só o factível, mas, igualmente, o que é possivel.

Se há sociedades pautadas por um poder nãocoercitivo, como sociedades do indiviso e do Múltiplo, pode-se perquirir sobre a origem e condições de existência da sociedade cujo poder é coerção, obrigatoriamente, como sociedades da divisão e do Uno. Se o Estado nasceu de uma revolução política, com a força mesmo de um desapego ao primitivismo, pode-se problematizar sua construção (e imaginar, diríamos, sua destruição).

Um retorno às raízes - eis a completude do movimento cíclico clastriano. E o que nos diz este movimento? Que, além da identificação "Estado é coerção", há íntima relação entre a Razão do Ocidente e a própria violência.

Muito embora ultrapasse o estruturalismo de LéviStrauss, Clastres dialoga com seu antigo professor do Collège de France no que concerne à similitude entre tais fatores. De fato, em Mitológicas, publicada em 1962, o antropólogo estruturalista apresenta a Razão como o fruto de uma cultura determinada, não como o fim último de todas as existentes, sendo um produto que elimina outras formas de pensar para afirmar-se como universal. O que faz o Estado clastriano senão recusar o Múltiplo, senão evocar o trabalho e a unidade como finalidades últimas da humanidade, colocando-se às margens aqueles deste centro afastados? Assim, [d]escobrimos no próprio espírito de nossa civilização, e coextensiva à sua história, a vizinhança da violência e da Razão, com a segunda não chegando a estabelecer seu reino a não ser através da primeira. A Razão ocidental remete à violência como à sua condição e ao seu meio, pois tudo aquilo que não é ela própria encontra-se em "estado de pecado" e cai então no campo insuportável do desatino. E é segundo essa dupla face do Ocidente, sua face completa, que deve se articular a questão da sua relação com as culturas primitivas.(CLASTRES, 2003, p. 34)

É inevitável concordar com Clastres (2003, p. 40): "É da revolução copernicana que se trata" pois a reflexão sobre o poder realiza, doravante, uma “conversão heliocêntrica":o poder político não é mais confundido tão-somente com a coerção e com a desigualdade, posto que se conceba seu oposto e se reflita sobre as bases de nossa civilização (talvez desgastadas) para podermos, querendo, transformá-las.

\section{Conclusão}

Pela leitura dos escritos de Pierre Clastres, restanos claro que a investigação do poder nas ditas sociedades primitivas não tem interesse apenas aos etnólogos, conquanto requerem do leitor, tacitamente, uma releitura de seus próprios valores como um contraste necessário.

Em verdade, a antropologia política, tal como descrita pelo filósofo e antropólogo, carecia de considerações maiores que abrangessem também o poder político existente nas sociedades indígenas. Nestas, ao contrário do que comumente se antevê ao poder na Filosofia Política tradicional, a coerção e a hierarquização das relações sociais não são os marcos distintivos do político, mas, sim, de sua degeneração.

Logo, Clastres acaba por, inevitavelmente, colocar suas conclusões perante o leitor como um espelho, ao empreender os esforços pela constituição de uma antropologia politica geral que, simultaneamente, se afirma como uma contracorrente ao bojo filosófico então desenvolvido. Vemo-nos mais que as próprias comunidades retratadas, pois, como em toda cultura, somos levados a universalizar as 
categorias de nosso pensamento e instituições. Mas, neste exercício, somos levados a conceber, também, como nossa razão é um produto tão efêmero como as demais criações culturais, embora seja o mais violento dos modos.

Nega-se às sociedades indígenas a condição de políticas e isto determina não tão-só o respeito (ou falta dele) à sua organização social, mas sua própria existência, que passará a ser tutelada pelo Estado, um benfeitor. $\mathrm{Na}$ infância dos povos, precisando desenvolver-se, todos os povos reunidos sob o signo da diversidade são suprimidos sob o argumento de sua condição inferior.

Por essa razão, a investigação clastriana do poder político ecoa para além das fronteiras da ciência social de que parte. Exemplo disso (embora não tenha sido o foco da etnologia clastriana) é o regime jurídico vigente no Brasil, e em outros Estados sul-americanos, de caráter assimilacionista quanto às populações indígenas: para o direito indigenista, a condição de sujeitos de direitos dos povos indígenas é vista com reticência, uma vez que para sua plenitude exigir-se-ia o reconhecimento de seu direito à autodeterminação e à diversidade. Especificamente nos estudos clastrianos, no entanto, é possível compreender como estas sociedades se organizam contrariamente à violência ínsita aos Estados e à razão que os condiciona: o poder político não é coercitivo, mas solidário.

Colocando-nos em contato com o Outro, questionamo-nos sobre as circunstâncias que definem nosso olhar e que, por conseqüência, definem a alteridade. As sociedades com Estado acabam por ser o ponto de chegada, se for dada a vontade de transformá-la. Aliás, tanto a Filosofia como a Antropologia possibilitam compreender outras formas de ordenação de nossa realidade, examinando-a criticamente e de modo a extirpar hábitos e vícios do entendimento que, embora tidos como universais, são contingentes e culturais.

As sociedades sem Estado são, na verdade, sociedades contra o Estado; são sociedades contra a desigualdade, contra a produção excedente; são sociedades contra o Uno. O mesmo Uno, talvez, questionado, outrora, por La Boétie, como a indecifrável fonte de poder coercitivo a qual tantos servos se submetem, seres inominados.

\section{Referências}

BOÉTIE, Étienne de la. Discurso de la servidumbre voluntaria. Madrid: Trotta, 2008.

CLASTRES, Pierre. A sociedade contra o Estado: pesquisas de antropologia política. São Paulo: Cosac \& Naify, 2003.

- Arqueologia da violência: pesquisas de antropologia política. São Paulo: Cosac \& Naify, 2004.

ENGELS, Friedrich; MARX, Karl. Manifesto comunista. São Paulo: Boitempo, 2007.

GIANNOTTI, José Arthur. Trabalho e reflexão: ensaios para uma dialética da sociabilidade. São Paulo: Brasiliense, 1983.

HOBBES, Thomas. Leviatã, ou, matéria, forma e poder de um estado eclesiástico e civil. 2. ed. São Paulo: Martins Fontes, 2008.

JECUPÉ, Kaká Werá. Ore Awé Roiru'a Ma: todas as vezes que dizemos adeus. Campinas: Troim, 2002.

LÉVI-STRAUSS, Claude. Tristes trópicos. São Paulo: Companhia das Letras, 2004.
Recebido em: julho de 2010 Aceito em: outubro de 2010 
